THE HUMAN DIFFERENCE 



\title{
THE HUMAN DIFFERENCE
}

\section{Animals, Computers, and the Necessity of Social Science}

\author{
ALAN WOLFE
}


Portions of this book have appeared in somewhat different form in the following articles: "Sociological Theory in the Absence of People: The Limits of Luhmann's Systems Theory," Cardozo Law Review 13 (March 1992): 1729-43; "Mind, Self, Society and Computer: Artificial Intelligence and the Sociology of Mind," American Journal of Sociology 96 (March 1991): 1073-96; "Social Theory and the Second Biological Revolution," Social Research 57 (Fall 1990): 615-48; "Up from Humanism," The American Prospect, Winter 1991, pp. 112-27; "Algorithmic Justice," Cardozo Law Review 11 (July/August 1990): 1409-34; "Sociology as a Vocation," American Sociologist 21 (Summer 1990): 136-48; and "Books vs. Articles: Two Ways of Publishing Sociology," Sociological Forum 5 (September 1990): 477-89.

University of California Press

Berkeley and Los Angeles, California

University of California Press, Ltd.

Oxford, England

(c) 1993 by

The Regents of the University of California

\section{Library of Congress Cataloging-in-Publication Data}

Wolfe, Alan, 1942-

The Human difference : animals, computers, and the necessity of social science / Alan Wolfe.

p. $\quad$ cm.

Includes bibliographical references and index.

ISBN 0-520-08013-o (alk. paper)

1. Sociology-Methodology. 2. Social sciences-

Methodology. 3. Sociobiology. 4. Human ecology. 5. Computers-Social aspects. I. Title. $\mathrm{HM}_{24}$. W6 641993 301'.01-dero

Printed in the United States of America
$\begin{array}{lllllllll}1 & 2 & 3 & 4 & 5 & 6 & 7 & 8 & 9\end{array}$

The paper used in this publication meets the minimum requirements of American National Standard for Information Sciences-Permanence of Paper for Printed Library Materials, ANSI Z $39 \cdot 48-1984$. 
The difference between facts which are what they are independent of human desire and endeavor and facts which are to some extent what they are because of human interest and purpose ... cannot be got rid of by any methodology. The more sincerely we appeal to facts, the greater is the importance of the distinction between facts which condition human activity and facts which are conditioned by human activity.

John Dewey 
This book is dedicated to my children, Rebekka, Jan, and Andreas. 